\title{
Presidential Biography
}

\section{Wanda W. Coluins}

\author{
President of ASHS: 1997-1998 \\ BS North Carolina State Univ., 1971 \\ MS (2) North Carolina State Univ., 1974 \\ PhD North Carolina State Univ., 1976
}

Wanda Collins was born in Windsor, N.C., on 18 June 1945 . She grew up in the small community of Midway and attended public schools in Merry Hill and Windsor. Her family did not live on a farm, but her father owned a farm, and Wanda was introduced early to agriculture in a rural area dependent on tobacco and peanuts. She did not find the early experience extremely pleasant and decided to become a mathematician. However, she eventually enrolled in a biology curriculum at North Carolina State Univ. (NCSU) and graduated with high honors in 1971.

Having been exposed at NCSU to the more esoteric side of agriculture, and on the advice of a trusted and valued mentor, Dr. Samuel Jenkins, she entered graduate school to pursue a double degree in Plant Pathology and Genetics. She received Master of Science degrees in 1974 under the advisorship of Dr. Lowell Nielsen, in plant pathology, and Dr. Robert Moll, in genetics, completing research on the nature of resistance to Fusarium wilt in sweetpotatoes and so beginning a long career in a little-researched crop. Collins followed that line of research into a $\mathrm{PhD}$ program, again in both departments and under the same advisors, and received the $\mathrm{PhD}$ in 1976 with a dissertation that emphasized the genetic mechanism of resistance to Fusarium wilt in sweetpotatoes.

Following the $\mathrm{PhD}$ degree, Collins was employed by the Dept. of Horticultural Science at NCSU as an assistant professor with a $100 \%$ research responsibility for sweetpotato breeding and genetics. She advanced through the ranks and became a full professor in 1986 . In Nov. 1997, she joined the International Potato Center (CIP) in Lima, Peru, as Deputy Director General for Research with responsibility for the $\$ 16$ million research agenda of the Center.

During the period from 1976 to 1986 , Collins concentrated on sweetpotato breeding and genetics for U.S. conditions and developed a wide-ranging research program in collaboration with fellow researchers in plant pathology, food science, and entomology. She also collaborated with sweetpotato scientists in other U.S. universities and was active in the U.S. National Sweetpotato Collaborators Group, serving as Chair of the Group for 1 year. In 1986, Collins took on the added responsibility of potato breeding and genetics at NCSU and again developed a wide-ranging breeding and genetics program. She concen-

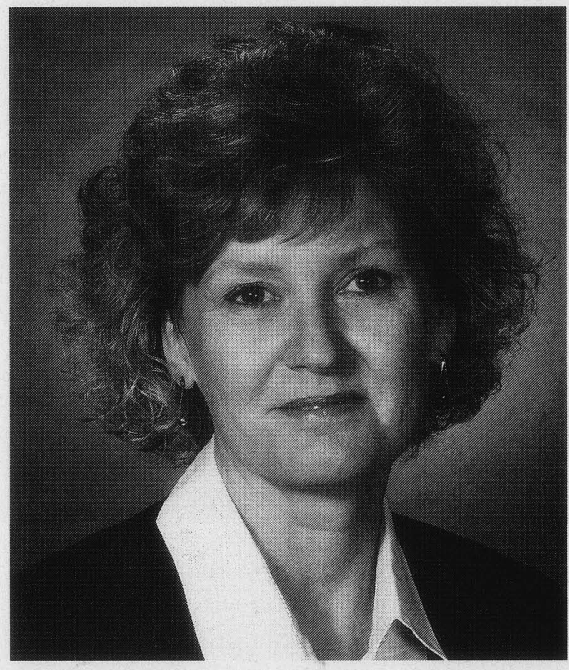

tional Agricultural Research (CGIAR). The 1year leave was extended to 3 years when she took on the responsibility of managing a Swedish-funded project to study global policy development in genetic resources, and also the responsibility as Senior Technical Advisor for the Banana Improvement Program, an international research fund for banana improvement.

Collins' strong interest and expertise in global genetic resources and policy issues developed as a result of having served 6 years on the U.S. National Plant Genetic Resources Board and 7 years as a member of the Board of Trustees of the International Plant Genetic Resources Institute (IPGRI). From 1993 to 1997 she served as the Chair of the IPGRI Board as well as the Chair of the Board of Trustees of INIBAP, the International Network for the Improvement of Banana and Plantain. She is co-editor of a book, "Biodiversity and Agroecosystems," that was published in Aug. 1998.

Collins has developed additional interests trated heavily in the training of graduate students, especially non-U.S. graduate students, and has advised more than $25 \mathrm{MS}$ and $\mathrm{PhD}$ students.

During 1986, Collins spent a study leave at CIP in Lima, Peru, and began the first steps of developing an extensive international breeding program in sweetpotatoes. As a result of that program, sweetpotato germplasm developed by Collins has been tested throughout the world and varieties have been released in five countries outside the United States. She also served in a consulting capacity for CIP as a global advisor on sweetpotato research priorities in developing countries. In that capacity, she participated in priority-setting exercises in all major sweetpotato-growing regions of the world, including Latin America, Africa, and Asia, and grew increasingly aware of the potential for this underresearched and underutilized crop in meeting threats to global food security in developing countries. From 1991 to 1997 , she served as the USAID liaison scientist to CIP.

In 1995, Collins joined the World Bank Vice Presidency for Environmentally and Socially Sustainable Development for a 1-year USAID-sponsored study leave as an agricultural research advisor on global issues. She was part of a small, international team studying the emergence of a global agricultural research system. Her particular responsibilities included working to increase the role of U.S. universities in that system, and working with international agricultural research centers of the Consultative Group on Interna- and expertise in policy issues dealing with biotechnology and biosafety and with intellectual property rights in global agricultural research through her World Bank responsibilities. In Oct. 1997, she co-organized an international event in biosafety issues under the sponsorship of the World Bank and was co-editor of the proceedings that was published as a book in Nov. 1998. She was also co-editor of another book published in May 1998 entitled "Global Genetic Resources: Access and Property Rights," which is the proceedings of an international conference on intellectual property rights held in 1997, co-sponsored by ASHS, and for which she served as Co-Chair.

During her career in horticulture, Collins has served in many regional and national positions in ASHS, including Vice-President of the International Division. She has served on numerous committees. Along with students and collaborators, she has published almost 50 peer-reviewed articles and numerous book chapters and extension and popular articles. She is a member of Gamma Sigma Delta and Phi Kappa Phi honor societies and has been elected Fellow in both ASHS and the American Association for the Advancement of Science.

Collins currently resides in Lima, Peru. She is married to Carroll Collins and has one son, Chris, both of whom live in North Carolina. 